\title{
BARTOSZ MAJCHRZAK
}

\author{
Cardinal Stefan Wyszyński University in Warsaw
}

\section{THE AXIOLOGY OF ADMINISTRATIVE LAW FUNDAMENTAL ISSUES}

\section{INTRODUCTORY REMARKS}

In recent years an increase may be observed in the interest in publications on the law in issues relating to values in administrative law $^{1}$. Naturally enough, the importance of such questions can hardly be overrated, since for many authors the axiology of administrative law serves as the very foundation for the definition of the concept of "administrative law" itself 2 . In particular, according to Z. Cieślak, administrative law is the set of legal norms arranged in an established order whose validity is endorsed by the fact that the public administrative

1 E.g. Wartości w prawie administracyjnym, ed. J. ZImmermann, Warszawa 2015; Antywartości w prawie administracyjnym, ed. A. BŁAś, Warszawa 2016; Aksjologia prawa administracyjnego, ed. J. ZIMMERMANN, Warszawa 2017, I-II, Warszawa 2017; Values in Global Administrative Law, eds. G. Anthony, J-B. Auby, J. Morison and T. Zwart, Oxford and Portland 2011.

2 S. Fundowicz, Dobro w prawie administracyjnym, [in:] Amicus hominis et defensor iustitiae. Przyjaciel człowieka i obrońca sprawiedliwości. Księga Jubileuszowa w 70. Rocznicę urodzin Sędziego Ferdynanda Rymarza, eds. D. Dudek, M. GAPski, and W. ŁĄCzKowski, Lublin 2010, p. 162; J. FILIPEK, Metoda administracyjno-prawna, [in:] Prawo administracyjne w okresie transformacji ustrojowej, eds. E. Knosala, A. Matan, and G. Łaszczyca, Kraków 1999, pp. 43-44. 
agencies (of the Republic of Poland) apply them to implement the values laid down by the Constitution of the Republic of Poland ${ }^{3}$ and by other normative acts of legislation. These values constitute a collective category denoting the common good ${ }^{4}$. Hence a norm of administrative law is characterised by the fact that the purpose of an operation undertaken by a public administrative agency in compliance with the given norm is to implement the value for which the norm has been introduced.

The aim of this essay is to sort the complex issues involved in the axiology of administrative law and arrange them in a logical order, taking into consideration the publications which are accruing at a growing rate on the subject. I examine it from a specific perspective, summing up what has been written so far on its legal doctrine, which I treat as the point of departure for further study. My objective within this context is to reconstruct the nature, role, and catalogue of values in administrative law, and to classify them on the basis of a specific set of criteria. An important aspect of my approach will be to indicate the relations between the various values in the regulations of administrative law, and the mechanisms for the resolution of any collisions which may occur between them.

Before we embark on a study of the axiology of administrative law we shall have to accept a basic assumption, namely that the law is purposeful (instrumental) in character. It is applied by the legislator to accomplish the values he has selected, by means of the measures he has established for the achievement of those values, and has laid them down in a legal provision 5 . In other words, we must assume that the legislator is acting on a rational basis when he is instituting an

3 The Constitution of the Republic of Poland of 2 April 1997, Dziennik Ustaw [the official Polish journal of laws and statutes, hereinafter Dz.U.] No 78, item 483 as amended; hereinafter Polish Constitution.

4 Z. CIEślak, Określenie prawa administracyjnego, [in:] Prawo administracyjne, ed. Z. NiEWIADOMski, Warszawa 2013, p. 55.

5 O. Bogucki, Odtwarzanie celów i innych wartości z tekstu prawnego, [in:] W poszukiwaniu dobra wspólnego. Księga jubileuszowa Profesora Macieja Zielińskiego, eds. A. Choduń and S. Czepita, Szczecin 2010, p. 206; W. Gromski, Autonomia prawa i aksjologiczne uwarunkowania aktów jego instrumentalizacji, "Gdańskie Studia Prawnicze» IX/2002, pp. 218, 222; S. WrONKOWSKA-JAśKIEWICZ, Uwagi o instrumentalności, 
axiological norm. Hence the choice he makes of values which are to be protected by law also determines the nature of the provisions for their protection, and in particular can lead to the selection of the provisions of administrative law best suited for the achievement of those values. One more conclusion may be drawn from this - that a given legal provision cannot be separated off from the value which is determined by "the intermingling of the axiological factor with the normative factor"6. Thereby the values invoked by a legal provision "lend colour" to the obligation defined by that provision, while the provision enhances and re-defines the value ${ }^{7}$. In other words, we may come to a conclusion about the sense of the given value on the basis of the content of the legal provision; and conversely, the value tells us what the provision is like ${ }^{8}$.

\section{The CONCEPT OF VAlues IN ADMinistrative LAW} AND HOW THEY MAY BE RECONSTRUCTED

In colloquial language values are expressions for 1) things that are valuable; 2) things that we want, our current or potential objective, aim, or desire; 3) things that satisfy someone's needs or interests; 4) things that bring satisfaction or give pleasure; or 5) the condition or state a given person sets himself as his goal ${ }^{9}$. As I have already said, values come into the legal system, especially into the provisions of administrative law, by which - to put it as simply as possible - we mean the set of interrelated, mandatory norms of conduct regulating the structure and operations

instrumentalizacji i autonomii prawa, [in:] Aksjologia prawa administracyjnego, ed. J. Zimmermann, Warszawa 2017, I, Warszawa 2017, p. 26.

6 'Votum separatum' of Z. Cieślak to the Judgement of the Polish Constitutional Tribunal of 7 May 2014, K 43/12, «OTK ZU» 5/A/2014, pos. 50.

7 Z. Cieślak, Trybunał Konstytucyjny - „prawotwórca” negatywny, [in:] Orzecznictwo w systemie prawa. II Konferencja Naukowa Wydziału Prawa i Administracji Uniwersytetu Gdańskiego oraz Wolters Kluwer Polska, Gdańsk, 17-18 września 2007, eds. T. BĄKowski, K. GrajeWski, and J. WARYLEWSKi, Warszawa 2008, pp. 63-65.

8 IDEM, Elementy konstrukcyjne układu administracyjnego, [in:] Nauka administracji, ed. Z. Cieślak, Warszawa 2017, p. 159.

9 Cf. A. B. StęPIEŃ, Wstęp do filozofii, Lublin 2001, p. 103. 
of public administration in the activities proper to it ${ }^{10}$ (viz. regulating public administration as regards the subject and method of its activities). In view of this values in the legal system may be defined as past, present, or future states or conditions which the legislator regards as valuable and therefore requiring protection by means of adequate legal provisions (e.g. of administrative law). We should also bear in mind that values are a relational category, relative to the standard of evaluation adopted by the person evaluating the given "condition or state of affairs," and that is why a thief's catalogue of values is different from that adopted by "an honest person." To sum up, a value in the legal system is an attribute of a given state or condition, thing, fact, or event, which the legislator ascribes to it when he assesses it as right or good in the light of the internalised standard of evaluation which he has adopted, which is entailed in the Constitution, and which thereby reflects the opinion held by the majority of society.

A value in the legal system will be the axiological foundation of a provision of administrative law if it is afforded protection (viz. implemented) in the norms of administrative law. This means that this particular value is to be directly implemented in the operations of public administrative agencies ${ }^{11}$. Or to put it in other words, a particular value will have the features of a value of administrative law if it can be directly implemented in the operations of an administrative authority, and the provision which protects that value is a provision of administrative law.

Furthermore, we may also say on this basis that the catalogue of values in the provisions of administrative law is determined by the legislator, who gives expression to his axiological preferences in the legislation he institutes. There are several legal constructions which are particularly significant for the reconstruction of the catalogue of these values. The first is the preamble to a normative act which formulates the aim of the given provision, thereby indicating its axiological

10 Cf. Z. Cieślak, Określenie prawa..., p. 55; J. Staroścıak, Prawo administracyjne, Warszawa 1978, p. 17.

11 Cf. Z. Cieślak, Określenie prawa..., p. 55. 
foundation ${ }^{12}$. The next relevant component are the principles behind the provision, in the sense of the legal norms which order or prohibit the implementation of a given value ${ }^{13}$, e.g. the principle of swiftness ${ }^{14}$ or the principle of sustainable development ${ }^{15}$. Another important category are the legal definitions, especially those which are applicable to the objective protection of a given legislative act and may be used to decode the values at its foundation, e.g. the definition referred to in Polish as ochrona środwiska (protection of the environment), formulated in Art. 3 Point 3 of the Polish legislative act Ustawa $z$ dnia 27 kwietnia 2001 r. - Prawo ochrony środowiska (the Protection of the Environment Act of 27 April 2001) ${ }^{16}$. This issue is connected with the construction of the so-called "not fully defined concepts," the essence of which boils down to the relative freedom encoded in them the administrative agency concerned enjoys to assess the merits of each particular case from the point of view of values ${ }^{17}$ - e.g. the expression przemawiaja za tym względy ochrony środowiska (considerations of environmental protection support/speak in favour of this), as used in Art. 196 Part 1 of the Protection of the Environment Act I have just cited. There are also provisions of a special kind which must not be overlooked in this respect: these are the "targeted" provisions which require particular persons or institutions to achieve a task implementing or oriented to implement a given value ${ }^{18}$, but they are not of fundamental importance to entire legal system as a whole or to its part, so they are not legal principles, e.g. the norm which may be reconstructed from the provision which says that

12 M. E. Stefaniuk, Preambuła aktu normatywnego $w$ doktrynie oraz $w$ procesie stanowienia i stosowania polskiego prawa w latach 1998-2007, Lublin 2009, p. 398.

13 M. Kordela, Zasady prawa. Studium teoretycznoprawne, Poznań 2012, p. 102.

14 Art. 12 of the Act of 14 June 1960 - Administrative Procedure Code, Dz.U. 2017 item 1257 as amended; hereinafter A.P.C.

15 Polish Constitution Art. 3.

16 Dz.U. 2017 item 519 as amended.

17 Z. CIeślak, Przepisy zawierające pojęcia niedookreślone, [in:] Prawo administracyjne, ed. Z. NiEWiadomski, Warszawa 2013, p. 74.

18 IDEM, Zbiory zachowań wadministracji państwowej. Zagadnienia podstawowe, Warszawa 1992, p. 63. 
"one of the basic tasks of the Police is to protect human life and health" (do podstawowych zadań Policji należą: ochrona życia i zdrowia ludzi) ${ }^{19}$.

This understanding of the values inherent in a legal system (in a system of administrative law) implies that they are normative in nature. This type of value (one which approves of a specific condition or state) is a component part of a legal norm (its disposition or hypothesis) and is expressed, explicitly or implicitly, in the provisions constituting the basis for the reconstruction of the norm. Hence the requirement that the given value be implemented in consequence of the given person's or institution's duty to act in accordance with the legal norm which has its axiological foundation in that value.

The legislator's axiological preferences are strictly connected with the administrative policy pursued by the state, and hence also with the definition of the aims to be pursued by its administrative agencies and the determination of the methods they are to apply to achieve those aims by legal and extra-legal means ${ }^{20}$. The definition of those aims "coincides" in its own, specific manner with the set of values due to be implemented which have been formulated in the state's Constitution. Hence a state's political aims may not clash with nor be contrary to its fundamental values. The introduction of a legal provision for the implementation of aims which stand in opposition to the legislator's values - a phenomenon known as "the political instrumentalisation of the law" 21 - would make that provision contrary to the Constitution, which would mean that it should be removed from the legal order.

While on the concept of value in administrative law, we should also consider the semantic relation of this expression to other fundamental concepts in the doctrine of administrative law. One of them is "the common good," in the sense of the sum total of all the values enshrined in the Constitution and other legislative $\operatorname{acts}^{22}$, in particular the values

19 Art. 2 (1) of the Police Act of 6 April 1990, Dz.U. 2017, item 2067.

20 Cf. Z. LeońsKi, Nauka administracji i polityka administracyjna, "Organizacja Metody Technika»11/1972, p. 9; P. SzReniawski, Ogólne i szczegółowe nauki administracyjne, Przemyśl and Rzeszów 2009, p. 42.

21 S. WronkowsKa-JAśKieWiCZ, op. cit., pp. 27-28.

22 Z. Cieślak, Określenie prawa..., p. 56. 
inherent in the provisions of administrative law. Thus "the common good" means all the conditions and states which the legislator considers good or right, and which therefore have been afforded legal protection. These specially selected values are strictly connected with the criteria determining individual, social, and public interest, since they relate to the conditions and states which have been approved by the legislator and which are advantageous respectively to individuals (individual persons, individual legal entities, or the individual units in an organised structure), social groups (up to and including the whole of society), and the state (as the formal organisation of society, its institutions, and its agencies) ${ }^{23}$. In addition the values of administrative law contributing to the common good may serve in the legal system as the aims or tasks pursued by public administration. By "aim" I mean the effort made to achieve a prospective, "envisaged" state of affairs or condition; while a "task" is "the favourable condition currently being implemented" leading to the achievement of the aforementioned aim ${ }^{24}$.

To illustrate this terminological distinction we may take Art. 112 of the Protection of the Environment Act I refer to above. Under this provision protection against noise means maintaining the acoustic environment in the best possible condition (this is the provision's aim), in particular by 1) keeping noise below or at least at the admissible level (this is a task); and 2) reducing noise at least to the admissible level, if in excess of the admissible level (this is also a task). Thus the protected value which is to be derived from Art. 112 is the non-occurrence of an excessive level of noise in the environment; and this value is in the social interest and contributes to the common good.

23 Cf. M. JAśKowska, Pojęcie interesu publicznego i jego funkcje w prawie administracyjnym, [in:] Teoria instytucji prawa administracyjnego. Ksiega pamiątkowa Profesora Jerzego Stefana Langroda, ed. J. Niczy PORUK, Paryż 2011, pp. 295-296; M. STAHL, Dobro wspólne $w$ prawie administracyjnym, [in:] Nowe problemy badawcze $w$ teorii prawa administracyjnego, eds. J. Boć, and A. CHAJBowicz, Wrocław 2009, p. 60.

24 Cf. Z. Cieślak, Zbiory zachowań..., p. 43. 


\section{Classification of the values of Administrative Law}

It is generally held that the provisions of administrative law are divided into those belonging to substantive law, those ascribed to procedural law, and those belonging to the law on the system of public administration $^{25}$, and the chief criterion differentiating them from one another is the subject which they regulate. Substantive law defines the rights and duties of the addressees of its provisions - primarily a country's citizens and other legal entities which are not subordinated by organisation or professional service to a public administrative agency. For instance, substantive law regulates the conditions for the issue and content of a licence for the sale of spirits and alcoholic drinks, or of a demolition order. Procedural law regulates the way in which these rights and duties are to be implemented (concretised) by means of an administrative decision. The law on the administrative system regulates the structure and organisation of administrative agencies, their creation and the appointment of their staff, the scope of their tasks and powers, and the relations between particular administrative bodies ${ }^{26}$.

An equally important factor differentiating between the above types of regulations in administrative law is the set of axiological foundations on which the legislator establishes their respective legal norms. In this respect we have two kinds of values - objective values, and instrumental values. Objective values - for instance health or state security - are conditions which are protected by substantive administrative law, and their direct implementation is the basic motive for the work of public administration. Instrumental values serve to implement objective values,

25 E.g. Z. Duniewska, Prawo administracyjne: materialne, proceduralne i ustrojowe, [in:] System prawa administracyjnego. Instytucje prawa administracyjnego, eds. R. Hauser, Z. Niewiadomski, and A. Wróbel, I, Warszawa 2015, p. 131.

26 Cf. W. Dawidowicz, Zagadnienia ustroju administracji państwowej w Polsce, Warszawa 1970, pp. 18, 31; Z. NiewiAdomski, Pojęcie prawa procesowego i jego relacje z prawem materialnym i ustrojowym, [in:] Prawo administracyjne. Część procesowa, ed. Z. Niewiadomski, Warszawa 2002, p. 13; ElżBieta Ura and Edward Ura, Prawo administracyjne, Warszawa 2004, p. 30. 
and hence have the nature of a proficiency ${ }^{27}$. They may be sub-divided into procedural values (viz. values proper to administrative procedure), and systemic values, which are to be achieved within the provisions of the law on the system of public administration.

With regard to the list of general principles for administrative procedure formulated in Arts. 6 - 16 of the Polish Code of Administrative Proceedings (hereinafter A.P.C.), when we consider the instrumental values we shall have to take special note of the following: 1) the thorough examination of the state of affairs pertaining to the case in question; 2) the comparison and weighing up of the respective interests of the state, the communities concerned, and the citizens; 3 ) the impartiality (fairness) and objective character of the work of the administrative agencies concerned; 4) swiftness; 5) arbitral settlement of disputed issues; 6) resolution of the administrative problem in compliance with the law; 7) the assumption that the administrative matter has been settled appropriately; and 8) the relative permanence of the administrative settlement of the matter. In the catalogue of systemic instrumental values we should pay special attention to values like 1) the quantitatively and generically best possible allocation of powers to the various administrative agencies; 2) the precise and separable allocation of powers to the various administrative agencies ${ }^{28}$; 3) the relative independence of activities pursued by socialised public administrative agencies; 4) subsidiarity (viz. the devolution of powers to lower-tier administrative units to ensure operations "as close as possible to the individual citizen"); 5) systemic coherence of operations by the various administrative agencies (due to their interrelations on the basis of systemic administrative law); 6) public service (in the sense of the administrative officer's impartiality and fairness, thoroughness, his professional approach to his work, and his sense of loyalty and honesty with respect to the state and society as a whole).

27 Z. Cieślak, Określenie prawa..., pp. 56-58; W. Federczy , Badania podstaw aksjologicznych prawa procesowego w zakresie jawności i jej ograniczeń, [in:] Jawność i jej ograniczenia. Podstawy aksjologiczne, ed. Z. CIeśla , II, Warszawa 2013, p. 102.

28 Cf. Z. Cieśla K, Zasady prawa administracyjnego, [in:] Prawo administracyjne, ed. Z. Niewiadomski, Warszawa 2013, p. 63. 
As I have already observed, the essential core and overriding goal of the work conducted by public administration are the objective values which lie at the basis of administrative substantive law. Values of this kind may be arranged in an order according to the extent of the benefit and advantages a given person, group or institution receives when such values are achieved. Thus we may identify the objective values focusing on a) the public interest (viz. values which bring a benefit to the state as the formal organisation of society, its institutions and agencies, the "community" of state institutions and society as a whole); b) the social interest (values which bring a benefit to social groups or to the whole of society); and c) the interest of individuals.

In view of the position of the Constitutional norms in the legal system, the objective values which are of fundamental significance for the operations of the public administrative agencies (as well as for other entities of public authority) are those values which are enshrined in the Constitution. In particular, the axiological principles lodged in the Polish Constitution regulating administrative substantive law and relating specifically to the public interest, are as follows: democracy, social justice, the unity of the state, its territorial indivisibility and inviolability, the rule of law, the decentralisation of public authority, the enjoyment of a legal personality by local government communities, autonomy of the churches and religions, and a balanced budget for the state. Objective values pertaining to social interest include national sovereignty, national identity and continuity, the national heritage, access to cultural assets, sustainable development, marriage and the family, freedom of association, solidarity and co-operation, freedom of the press and media, and access to a broad range of public information. Objective values relating to the individual's interest include life and health, the individual's personal inviolability and freedom, his access to justice in the courts of law, privacy, citizens' security, maternity and parenthood, freedom to engage in business activities, ownership, the right to work, and religious freedom ${ }^{29}$.

29 Cf. Idem, Model aksjologiczny, [in:] Nauka administracji, ed. Z. CieśLak, Warszawa 2017, p. 184. 
To protect these axiological principles the legislator institutes appropriate provisions of substantive administrative law which may directly invoke the values prescribed in the Constitution, or alternatively refer to them indirectly, by bringing in more detailed values to operationalise the specific selection made at the constitutional level ${ }^{30}$. For example, the constitutional value of sustainable development is particularised in the axiology of the Polish Protection of the Environment Act I have referred to above, and the particulars are as follows: the balance of nature; comprehensive environmental protection, and clean air. Access to cultural assets is a protected value under the Polish Constitution, and was given a precise formulation in the Protection and Care of Cultural Heritage Act of 23 July 2003 (Ustawa $z$ dnia 23 lipca 2003 r. o ochronie zabytków i opiece nad zabytkami) ${ }^{31}$, as a value comprising the enduring preservation of the national heritage. Ownership (the right to own property) as a constitutional value is elaborated in the building freedom protected under the Polish Building Law of 7 July 1994 (ustawa $z$ dnia 7 lipca 1994 r. - Prawo budowlane) ${ }^{32}$. Thus what we have, especially at the level of axiological principles, is a sort of coalescence of some of the components of administrative law and constitutional law. The norms of both of these kinds of legal regulations share and jointly implement the same values enshrined in the Constitution, though of course each in its specific way, by means of its own regulations. However, in no way does this diminish our conclusion that there is a strong and permanent link connecting the constitutional and administrative norms ${ }^{33}$. Sometimes administrative law is even called "concretised constitutional law" 34

\footnotetext{
30 Cf. ibidem, p. 185.

31 Dz.U. 2017 item 2187 as amended.

32 Dz.U. 2017 item 1332 as amended.

33 J. Łętowski, Prawo administracyjne. Zagadnienia podstawowe, Warszawa 1990, p. 18.

34 E.K. Pakuscher, Administrative Law in Germany - Citizen v. State, "American Journal of Comparative Law»16.3/1968, p. 331; H. PünDER, Administrative Procedure Mere Facilitator of Material Law versus Cooperative Realization of Common Welfare, [in:] Debates in German Public Law, eds. H. Pünder and C. WAldhoff, Oxford and Portland, Oreg. 2014, p. 245.
} 
a more detailed, precise and particularised, more fully defined version of constitutional law ${ }^{35}$.

\section{Relations between the Values of administrative LaW} AND WHAT HAPPENS WHEN THEY COLLIDE WITH EACH OTHER

An examination of the axiological foundations of administrative law, especially if conducted from the point of view of particular legislative acts involving substantive law (i.e. legislation which regulates matters handled by public administrative authorities) and a review of the procedural and systemic norms associated with them, allows us to say that the values contributing to the foundation of these norms may either "adjoin" each other, "collide" with one another, or "take up a neutral position" with respect to each other ${ }^{36}$. Thereby, in the first place, they may form sequences of jointly protected values. For instance, on the grounds of the Polish Access to Public Information Act of 6 September 2001 (Ustawa $z$ dnia 6 września 2001 r. o dostępie do informacji publicznej) ${ }^{37}$ we can identify the following set of values in the following order with respect to each other: access to a broad range of public information citizens' participation in government - transparency in the operations of a public authority - its operational efficiency. Secondly, values may clash with each other, if the implementation of one value is achieved "at the cost" of the achievement of another value (e.g. state security and public order versus access to a broad range of public information; or accurate fact development regarding a particular case versus procedural swiftness). Thirdly, we may have the situation where the achievement of one value is neutral with respect to the implementation of another

35 J. Schwarze, Enlargement, the European Constitution, and Administrative Law, «International and Comparative Law Quarterly» 53.4/2004, p. 978.

36 Cf. Z. Cieślak, Aksjologiczne podstawy jawności. Perspektywa nauk o administracji, [in:] Jawność i jej ograniczenia. Podstawy aksjologiczne, ed. Z. Cieślak, II, Warszawa 2013, p. 6.

37 Dz.U. 2016 item 1764 as amended. 
value (e.g. unity of the state in relation to religious freedom; or the right to work in relation to access to a broad range of public information).

Naturally enough, collisions for special concern occur when there is a clash of two axiological principles of administrative law. When this happens a decision has to be made which of them is to be prioritised and implemented, and which is to be treated as of secondary importance or not implemented at all. The "tension" in such situations of conflict may be reduced 1) at the legislative stage, if the legislator clearly states which value is to be "preferred," for example, if he stipulates that access to public information must be limited whenever there is a need to protect classified information, whereby access to a wide scope of information has to "give way" to state security and public order; 2) at the stage of the exercise of the law, when the legislator authorises a public administrative agency to weigh up the values involved in a case, for example, by permitting the administrative agency to exempt offenders from the whole or part of a fine in special cases justified on the grounds of an important public interest, or an important interest of the party concerned ${ }^{38}$.

The mechanisms for weighing up the values involved in administrative law find their expression in the relevant provisions. For the legislative stage the corresponding mechanism is described in the principle of proportionality ${ }^{39}$, which in the Polish legal order is derived from Arts. 2 and 31 Part 3 of the Constitution ${ }^{40}$. This principle defines the conditions which must be observed for the lawful restriction of the implementation of a given value for the sake of implementing another value. The following requirements must be met: a) purposefulness when the imposition of a limit to the implementation of a given value can in outcome lead to the achievement of another value; d) necessity the restriction is indispensable for the protection of the other value; and c) proportionality in the strict sense of the term - when the favourable

38 A.P.C. Art. $189 \mathrm{k}(1)$

39 Cf. A. Fogel, Prawna ochrona przyrody w lokalnym planowaniu przestrzennym, Warszawa 2011, p. 104.

40 E.g. Judgement of the Polish Constitutional Tribunal of 31 January 2013, K 14/11, «OTK ZU» 1/A/2013, item 7. 
outcome of the restriction, viz. the implementation of a given value, balances out the partial or full non-implementation of another value ${ }^{41}$.

At the next stage, in the exercise of the law, the administrator's duty to weigh up the conflicting values involved in a case is defined in the Polish legal order in Art. 7 of the A.P.C. and the principle laid down therein ordering the administrator to consider the social interest and the lawful interest of the citizens, and to harmonise the implementation of the values contributing to the social interest with those representing individual interest ${ }^{42}$ (viz. the interest of the parties to the administrative proceedings and others interested in the outcome of the case $)^{43}$. In other words, the administrator handling the case is bound to weigh up the clashing values with respect to one another - for instance values like ownership or freedom to conduct business activities against the state's balanced budget, weighed up against each other on the grounds of Art. $189 \mathrm{k} \$ 1$ of the A.P.C. Once the administrator has weighed up the values, he makes the decision which will achieve all the values involved in the case as fully as possible. In particular he has to decide which of the values should be prioritised and implement it to a high degree, and which of the values is to be implemented to a limited degree. In making this decision he is bound by the requirement of proportionality (viz. purposefulness, necessity, and proportionality in the strict sense of the term) $)^{44}$, and of the limit set on the protection of some of the values involved, on the grounds of Art. $8 \$ 1$ of the A.P.C., which says that "public administrative agencies conduct proceedings on the basis of the principle of proportionality, and in a manner which encourages the parties involved to trust in the fairness and reliability of public authority."

41 K. Wojтусzек, Granice ingerencji ustawodawczej w sfere prawa człowieka w Konstytucji RP, Kraków 1999, pp. 147, 159-160.

42 Cf. W. Federczy K, Mediacja w postępowaniu administracyjnym i sądowoadministracyjnym, Warszawa 2013, p. 77; M. Klimaszewski, Zasada uwzględniania interesu społecznego i stusznego interesu obywateli, [in:] W. FederCzy K, M. KLIMAszewski, and B. Majchrzak, Postępowanie administracyjne, Warszawa 2018, p. 26.

43 B. Adamiak, Uwagi do art. 7, [in:] B. Adamiak, J. Borkowski, Kodeks postępowania administracyjnego. Komentarz, Warszawa 2017, pp. 77-78.

44 J. Zakolska, Zasada proporcjonalności w orzecznictwie Trybunału Konstytucyjnego, Warszawa 2008, p. 18. 


\section{Closing Remark}

The observations I have made above show that there is an abundance of issues involved in the axiology of administrative law. Moreover, the bibliography of the subject treats those I have addressed in this essay in a plethora of approaches - for instance, there are many ways in which concepts like values in the $\mathrm{law}^{45}$, the common $\operatorname{good}^{46}$, or the compilation of catalogues of values in the provisions of administrative law ${ }^{47}$ are understood. Therefore attempts to settle these problems are well worth the effort. We will not be able to make very much progress in the research on these questions until we reach a certain amount of consensus on the basic issues, and only then will our research results be comparable.

\section{AKSJOLOGIA PRAWA ADMINISTRACYJNEGo PODSTAWOWE ZAGADNIENIA}

\section{Streszczenie}

Artykuł dotyczy istoty, roli i katalogu wartości w prawie administracyjnym. Zrekonstruowano w nim znaczenie podstawowych pojęć związanych z aksjologią wskazanej gałęzi prawa, zasygnalizowano konstrukcje prawne będące źródłami odkodowania wartości administracyjnoprawnych oraz dokonano klasyfikacji tych wartości według przyjętych kryteriów porządkujących. Ponadto zwrócono uwagę na relacje występujące między poszczególnymi wartościami regulacji administracyjnoprawnej oraz mechanizmy rozstrzygania kolizji między nimi.

45 Cf. J. Zimmermann, Aksjomaty prawa administracyjnego, Warszawa 2013, pp. 75-76.

46 Cf. B. Majchrzak, Problem delimitacji regulacji administracyjnoprawnej $w$ systemie prawnym $w$ świetle orzecznictwa Trybunału Konstytucyjnego, Warszawa 2015, pp. 184-192.

47 Cf. K. Сносноwsкi, Aksjologia w prawie administracyjnym, [in:] Aksjologia prawa administracyjnego, ed. J. Zimmermann, Warszawa 2017, I, Warszawa 2017, p. 52-53. 
The Axiology of Administrative Law Fundamental Issues

\section{Summary}

This article addresses the nature, role, and catalogue of values in administrative law. I present a reconstruction of the basic concepts associated with this branch of the law; I describe the legal constructions which are the sources for the decoding of the values in administrative law; and I classify these values according to a set of criteria I have adopted. In addition I remark on the relations between particular values in the provisions of administrative law and the mechanisms to be applied to resolve collisions in the event of conflicting values.

Słowa kluczowe: prawo administracyjne; aksjologia; wartości merytoryczne; wartości instrumentalne; interes publiczny; interes społeczny; interes indywidualny.

Keywords: administrative law; axiology; objective values; instrumental values; public interest; social interest; individual interest.

\section{Bibliography:}

Adamiak B., Uwagi do art. 7, [in:] B. Adamiak and J. Borkowski, Kodeks postępowania administracyjnego. Komentarz, Warszawa 2017, p. 69-81.

Aksjologia prawa administracyjnego, ed. J. Zimmermann, Warszawa 2017, I-II, Warszawa 2017.

Antywartości w prawie administracyjnym, ed. A. BŁAś, Warszawa 2016.

BogucKi O., Odtwarzanie celów i innych wartości z tekstu prawnego, [in:] W poszukiwaniu dobra wspólnego. Księga jubileuszowa Profesora Macieja Zielińskiego, eds. A. Choduń and S. Czepita, Szczecin 2010, p. 195-213.

Сносношsкі K., Aksjologia w prawie administracyjnym, [in:] Aksjologia prawa administracyjnego, ed. J. ZimmermanN, Warszawa 2017, I, Warszawa 2017, p. 49-60.

CIEŚLAK Z., Aksjologiczne podstawy jawności. Perspektywa nauk o administracji, [in:] Jawność i jej ograniczenia. Podstawy aksjologiczne, ed. Z. CIEśLaK, II, Warszawa 2013, p. 1-11.

Cieślak Z., Elementy konstrukcyjne układu administracyjnego, [in:] Nauka administracji, ed. Z. CiEśLAK, Warszawa 2017, p. 157-159. 
Cieślak Z., Model aksjologiczny, [in:] Nauka administracji, ed. Z. CieśLAK, Warszawa 2017, p. 00-00182-186.

Cieśla Z., Określenie prawa administracyjnego, [in:] Prawo administracyjne, ed. Z. Niewiadomski, Warszawa 2013, p. 55-58.

Cieślak Z., Przepisy zawierające pojęcia niedookreślone, [in:] Prawo administracyjne, ed. Z. Niewiadomski, Warszawa 2013, p. 74-76.

CieślaK Z., Trybunał Konstytucyjny - „prawotwórca” negatywny, [in:] Orzecznictwo w systemie prawa. II Konferencja Naukowa Wydziału Prawa i Administracji Uniwersytetu Gdańskiego oraz Wolters Kluwer Polska Gdańsk, 17-18 września 2007, eds. T. BĄKOWSKI, K. GraJEWSKI, and J. WARYLEWSKI, Warszawa 2008, p. 61-67.

Cieślak Z., Zasady prawa administracyjnego, [in:] Prawo administracyjne, ed. Z. Niewiadomski, Warszawa 2013, p. 61-66.

Cieślak Z., Zbiory zachowań w administracji państwowej. Zagadnienia podstawowe, Warszawa 1992.

Dawidowicz W., Zagadnienia ustroju administracji państwowej w Polsce, Warszawa 1970

Duniewska Z., Prawo administracyjne: materialne, proceduralne i ustrojowe, [in:] System prawa administracyjnego. Instytucje prawa administracyjnego, eds. R. Hauser, Z. Niewiadomski, and A. Wróbel, I, Warszawa 2015, p. 131-155.

Federczy K W., Badania podstaw aksjologicznych prawa procesowego $w$ zakresie jawności i jej ograniczeń, [in:] Jawność i jej ograniczenia. Podstawy aksjologiczne, ed. Z. CIEśLAK, II, Warszawa 2013, p. 101-130.

Federczy K W., Mediacja w postępowaniu administracyjnym i sądowoadministracyjnym, Warszawa 2013.

Filipek J., Metoda administracyjno-prawna, [in:] Prawo administracyjne $w$ okresie transformacji ustrojowej, eds. E. Knosala, A. Matan, and G. ŁAszczYca, Kraków 1999, p. 41-48.

Fogel A., Prawna ochrona przyrody w lokalnym planowaniu przestrzennym, Warszawa 2011.

Fundowicz S., Dobro w prawie administracyjnym, [in:] 'Amicus hominis et defensor iustitiae’. Przyjaciel człowieka i obrońca sprawiedliwości. Księga Jubileuszowa w 70. Rocznicę urodzin Sędziego Ferdynanda Rymarza, eds. D. Dudek, M. GAPSKI, and W. ŁąCZKOWSKI, Lublin 2010, p. 161-169.

Gromsкi W., Autonomia prawa i aksjologiczne uwarunkowania aktów jego instrumentalizacji, «Gdańskie Studia Prawnicze» IX/2002, , p. 217-232. 
Jaśkowska M., Pojęcie interesu publicznego i jego funkcje w prawie administracyjnym, [in:] Teoria instytucji prawa administracyjnego. Ksiegga pamiątkowa Profesora Jerzego Stefana Langroda, ed. J. NiCzy PORuk, Paryż 2011, p. 287-300.

Judgement of the Polish Constitutional Tribunal of 31 January 2013, K 14/11, «OTK ZU» 1/A/2013, item 7.

Klimaszewski M., Zasada uwzględniania interesu społecznego i słusznego interesu obywateli, [in:] W. FederczyK, M. KLIMAszewski, and B. MajCHrZaK, Postępowanie administracyjne, Warszawa 2018, p. 26-27.

Kordela M., Zasady prawa. Studium teoretycznoprawne, Poznań 2012.

LeOŃski Z., Nauka administracji i polityka administracyjna, "Organizacja Metody Technika» 11/1972, p. 7-10.

Łętowski J., Prawo administracyjne. Zagadnienia podstawowe, Warszawa 1990. MajCHrZaK B., Problem delimitacji regulacji administracyjnoprawnej w systemie prawnym $w$ świetle orzecznictwa Trybunału Konstytucyjnego, Warszawa 2015.

Niewiadomski Z., Pojęcie prawa procesowego i jego relacje z prawem materialnym i ustrojowym, [in:] Prawo administracyjne. Część procesowa, ed. Z. NiEWIADOMSKI, Warszawa 2002, p. 11-14.

Pakuscher E. K., Administrative Law in Germany - Citizen v. State, "American Journal of Comparative Law»16.3/1968, p. 309-331.

PÜNDER H., Administrative Procedure - Mere Facilitator of Material Law versus Cooperative Realization of Common Welfare, [w:] Debates in German Public Law, eds. H. Pünder and C. Waldhoff, Oxford and Portland, Oreg. 2014, p. 239-260.

Schwarze J., Enlargement, the European Constitution, and Administrative Law, «International and Comparative Law Quarterly» 53.4/2004, p. 969-984.

Stahl M., Dobro wspólne w prawie administracyjnym, [in:] Nowe problemy badawcze $w$ teorii prawa administracyjnego, eds. J. Boć, AND A. Снајвоwicz, Wrocław 2009, p. 47-60.

Starościak J., Prawo administracyjne, Warszawa 1978.

STEFAniuk M. E., Preambula aktu normatywnego $w$ doktrynie oraz $w$ procesie stanowienia i stosowania polskiego prawa w latach 1998-2007, Lublin 2009. StęPIEŃ A. B., Wstęp do filozofii, Lublin 2001.

Szreniawski P., Ogólne i szczegółowe nauki administracyjne, Przemyśl and Rzeszów 2009

Ura E., Ura ED., Prawo administracyjne, Warszawa 2004. 
Values in Global Administrative Law, eds. G. Anthony, J-B. Auby, J. Morison, and T. Zwart, Oxford and Portland 2011.

Votum separatum of Z. CIEśLAK to the Judgement of the Polish Constitutional Tribunal of 7 May 2014, K 43/12, «OTK ZU» 5/A/2014, pos. 50.

Wartości w prawie administracyjnym, ed. J. Zimmermann, Warszawa 2015.

Wojtyczeк K., Granice ingerencji ustawodawczej w sfere prawa człowieka w Konstytucji RP, Kraków 1999.

WronKowSKA-JAśKIEWICZ S., Uwagi o instrumentalności, instrumentalizacji i autonomii prawa, [in:] Aksjologia prawa administracyjnego, ed. J. ZıмMERMANN, Warszawa 2017, I, Warszawa 2017, p. 25-36.

ZaKolska J., Zasada proporcjonalności w orzecznictwie Trybunału Konstytucyjnego, Warszawa 2008.

Zimmermann J., Aksjomaty prawa administracyjnego, Warszawa 2013. 